\title{
Measurement of acetyl-CoA carboxylase activity in isolated hepatocytes
}

\author{
Caspaar Bijleveld and Math J.H. Geelen \\ Laboratory of Veterinary Biochemistry, State University of Utrecht, Utrecht (The Netherlands)
}

(Received 18 November 1986)

Key words: Fatty acid synthesis; Enzyme regulation; Acetyl-CoA carboxylase; Digitonin; (Rat hepatocyte)

\begin{abstract}
An assay is described for acetyl-CoA carboxylase activity in isolated hepatocytes. The assay is based on two principles: (a) The hepatocytes are made permeable by digitonin. $64 \mu \mathrm{g}$ of digitonin per mg of cellular protein were most effective in exposing enzyme activity without a significant effect on mitochondrial permeability. (b) Enzyme activity is measured by coupling the carboxylase reaction to the fatty acid synthase reaction. The advantages offered by this procedure over existing assays are: (i) rapidity, (ii) no need to prepare cell extracts, (iii) absence of product inhibition, (iv) no interference by mitochondrial enzymes, (v) useful in systems with bicarbonate buffers, and (vi) simple separation of radioactive substrate from labelled products. Using this coupled enzyme assay a good correlation was observed between changes in the activity of acetyl-CoA carboxylase and changes in the rate of fatty acid synthesis in hepatocytes as effected by short-term modulators.
\end{abstract}

\section{Introduction}

Acetyl-CoA carboxylase (EC 6.4.1.2) catalyses the ATP- and bicarbonate-dependent carboxylation of acetyl-CoA to form malonyl-CoA. This reaction is the first committed step leading to de novo synthesis of long-chain fatty acids. A number of studies have identified acetyl-CoA carboxylase as the rate-limiting enzyme in the pathway and it is believed to be one of the key control points in fatty acid synthesis. The carboxylase exhibits very complex control features. Under different physiological conditions, changes in total carboxylase activity are governed by changes in the relative rates of enzyme synthesis and degradation [1], by changes in compartmentation [2] or by changes in the catalytic efficiency of the enzyme, brought about either by modulation of the aggregation state of the enzyme

Correspondence: M.J.H. Geelen, Laboratory of Veterinary Biochemistry, State University of Utrecht, P.O. Box 80.177 , 3508 TD Utrecht, The Netherlands. by citrate, long-chain acyl-CoA [3] and malonylCoA [4], or by changes in covalent phosphorylation of the enzyme protein [5].

Acetyl-CoA carboxylase activity is routinely measured by the bicarbonate-fixation assay, which involves incubation of an enzyme preparation with $\left[{ }^{14} \mathrm{C}\right]$ bicarbonate, acetyl-CoA, MgATP and usually citrate. The reaction is stopped by acid and reaction mixtures are subsequently dried at $50-70^{\circ} \mathrm{C}$. Enzyme activity is then represented by non-volatile and acid-stable radioactive products.

It has been shown that this bicarbonate-fixation assay in crude tissue extracts is not a correct measure of acetyl-CoA carboxylase activity [6]. First, interference by mitochondrial enzymes like pyruvate carboxylase results in bicarbonate fixation into compounds other than malonyl-CoA [6-8]. Secondly, malonyl-CoA decarboxylase activity has been observed in the mitochondria of a variety of animal tissues [9]. In tissue homogenates or celluar extracts with broken mitochondria, malonyl-CoA decarboxylase activity will interfere 
with the bicarbonate-fixation assay. Thirdly, the fatty acid synthase complex - present in the cytosol - will also catalyse the decarboxylation of malonyl-CoA both in the presence and absence of NADPH $[10,11]$. The accumulation of malonyl$\mathrm{CoA}$ in the bicarbonate-fixation assay allows a significant decarboxylation of this reaction product. Fourthly, accumulated malonyl-CoA will inhibit acetyl-CoA carboxylase [4].

The aforementioned difficulties concerning the determination of acetyl-CoA carboxylase activity may have led to erroneous results and may have been partially responsible for the confusion with respect to the regulation of acetyl-CoA carboxylase activity. The situation may have been further complicated by incomplete inhibition of the enzymes modifying carboxylase activity, leading to changes in this activity during homogenization and in the time between homogenization and assay. In this way the effects of certain modulators on enzyme activity may have been missed or misrepresented. Factors responsible for erroneous results can be eliminated by purifying the carboxylase preparations. However, during such a timeconsuming process the activity of the enzyme is likely to change. The aim of the present work was to design a procedure for quick measurement of cellular acetyl-CoA carboxylase activity so that the influence of carboxylase-modifying enzyme systems is minimal. In addition, the assay should not suffer from interference by mitochondrial and cytosolic enzymes.

In the studies presented, isolated hepatocytes have been employed. In a one-step procedure digitonin permeabilizes the plasma membrane of the cells without affecting mitochondrial permeability and at the same time a coupled assay measures acetyl-CoA carboxylase activity. In the coupled assay malonyl-CoA formed is immediately converted into fatty acids by added fatty acid synthase and excess NADPH. In this way, malonylCoA will not accumulate to levels which inhibit carboxylase activity, and significant decarboxylation of malonyl-CoA is prevented.

\section{Materials and Methods}

Sources of materials. ${ }^{3} \mathrm{H}_{2} \mathrm{O}(5 \mathrm{Ci} / \mathrm{ml})$ and $\mathrm{NaH}^{14} \mathrm{CO}_{3}(57 \mathrm{Ci} / \mathrm{mol})$ were supplied by
Amersham International, Amersham; $\left[1-{ }^{14} \mathrm{C}\right]$ acetyl-CoA $(54.3 \mathrm{Ci} / \mathrm{mol})$ and $\left[2-{ }^{14} \mathrm{C}\right]$ malonyl-CoA $(45.5 \mathrm{Ci} / \mathrm{mol})$ were obtained from New England Nuclear, Boston, MA; digitonin, collagenase type I, 2-oxoglutarate, pyruvate, malonyl-CoA, acetylCoA and butyryl-CoA were purchased from Sigma, St. Louis, MO; Hepes, ATP, NADH and NADPH were from Boehringer, Mannheim; other chemicals were from Baker, Deventer. Insulin and glucagon were kindly donated by Lilly Research Laboratories, Indianapolis, IN.

Animals. Male Wistar rats (225-250 g) were used in all experiments. Liver cells were obtained from rats which had free access to water and were meal-fed a stock, pelleted diet between 4 and 7 a.m. The animals were killed between 9 and 10 a.m.

Isolation of enzymes. Hepatic acetyl-CoA carboxylase was isolated from rats starved $72 \mathrm{~h}$ and then refed a fat-free, high-sucrose diet for 48 $h$. The method employed was adopted from procedures described by Holland et al. [12] and by Nakanishi and Numa [13]. Briefly, the ammonium sulphate fraction $(0-30 \%)$ of the Nakanishi and Numa procedure [13] was loaded onto a Sepharose 2B column, and the fraction containing acetyl-CoA carboxylase activity was concentrated with ammonium sulphate and applied onto an avidinSepharose column as described by Holland et al. [12]. Carboxylase was recovered from this column by elution with biotin. It was concentrated with ammonium sulphate, dialysed and stored at $-20^{\circ} \mathrm{C}$.

Fatty acid synthase was purified from rat liver according to Linn [14], and stored at $-80^{\circ} \mathrm{C}$. The donor animals were pretreated as described above for the isolation of the carboxylase.

Isolation of rat hepatocytes. Hepatocytes were isolated and purified essentially according to the procedure of Seglen [15], except that the operational temperature was maintained at $37^{\circ} \mathrm{C}$ throughout [16]. In order to minimize glycogenolysis, glucose $(20 \mathrm{mM})$ was added to the perfusion buffer and to all buffers subsequently employed in the isolation procedure [17]. Isolated hepatocytes were suspended in Krebs-bicarbonate buffer supplemented with $10 \mathrm{mM}$ glucose and $1 \%(\mathrm{w} / \mathrm{v})$ defatted and dialysed bovine serum albumin. Incubations were carried out in a metabolic shaker 
(90 strokes $/ \mathrm{min}$ ) at $37^{\circ} \mathrm{C}$ in $25-\mathrm{ml}$ Erlenmeyer flasks which normally contained approximately 6 $\mathrm{mg}$ of cellular protein $/ \mathrm{ml}$. During incubation the flasks were continuously gassed with $95 \%$ oxygen and $5 \%$ carbon dioxide.

Analyses. To monitor rates of de novo fatty acid synthesis ${ }^{3} \mathrm{H}_{2} \mathrm{O}(0.5 \mathrm{mCi} / \mathrm{ml})$ was added to the cellular incubations. The incubations were terminated by the addition of chloroform/ methanol $(1: 1, v / v)$. Lipids were extracted according to Sundler et al. [18]. Total lipids were saponified at $75^{\circ} \mathrm{C}$ for $2 \mathrm{~h}$ with $0.3 \mathrm{M} \mathrm{NaOH}$ in $90 \%(\mathrm{v} / \mathrm{v})$ methanol: The saponifiable fraction was extracted with petroleum-ether (b.p. $40-60^{\circ} \mathrm{C}$ ) and counted for radioactivity. Lactate dehydrogenase was assayed using the procedure of Bergmeyer and Bernt [19]. Glutamate dehydrogenase was measured as described in Ref. 20. Protein was determined by the Lowry method [21].

Measurement of acetyl-CoA carboxylase activity. $100 \mu 1$ of hepatocyte suspension containing about $0.6 \mathrm{mg}$ of protein were added to Eppendorf cups holding $100 \mu 1$ of pre-heated $\left(37^{\circ} \mathrm{C}\right)$ isotonic assay mixture supplemented with digitonin. After closing the lid and gentle vortexing for $5 \mathrm{~s}$ the cups were incubated, without shaking, at $37^{\circ} \mathrm{C}$. Reactions were stopped after $4 \mathrm{~min}$ by addition of $100 \mu 110 \mathrm{~N} \mathrm{NaOH}$.

The total incubation mixture contained: Hepes (pH 7.5), $63 \mathrm{mM} ; \mathrm{MgCl}_{2}, 1.5 \mathrm{mM} ; \mathrm{MgSO}_{4}, 0.6$ $\mathrm{mM}$; citrate, $0.5 \mathrm{mM}$; EGTA, $2.5 \mathrm{mM}$; $\mathrm{CaCl}_{2}$, $1.25 \mathrm{mM} ; \mathrm{NaHCO}_{3}, 22.5 \mathrm{mM}$; NaCl, $70.5 \mathrm{mM}$; ATP, $2.0 \mathrm{mM}$; NADPH, $0.5 \mathrm{mM}$; dithioerythritol, $0.44 \mathrm{mM}$; bovine serum albumin, $0.925 \%(\mathrm{w} / \mathrm{v})$; digitonin, $38 \mu \mathrm{g} / 100 \mu \mathrm{l}$ pre-heated isotonic assay mixture; $\left[1-{ }^{14} \mathrm{C}\right]$ acetyl-CoA, $0.062 \mathrm{mM}(4 \mathrm{Ci} / \mathrm{mol})$; butyryl-CoA, $0.062 \mathrm{mM}$; fatty acid synthase, 3.0 $\mathrm{mU}$. (Before use fatty acid synthase was preincubated for $30 \mathrm{~min}$ at room temperature with 12.5 $\mathrm{mM}$ dithioerythritol. The activity of fatty acid synthase was determined by measuring the incorporation of $\left[2-{ }^{14} \mathrm{C}\right] \mathrm{malonyl}-\mathrm{CoA}$ into fatty acids. One unit of fatty acid synthase equals $1 \mu \mathrm{mol}$ malonyl-CoA incorporated into fatty acids per $\min$ at $37^{\circ} \mathrm{C}$.)

The digitonin-containing assay mixture is prepared within $15 \mathrm{~min}$ before use by mixing a known amount of digitonin - which is dissolved in an
EGTA stock solution by heating in a boiling waterbath - with the other components of the assay mixture.

The contents of the Eppendorf cups were transferred to extraction tubes with three aliquots of $300 \mu 1$ of $0.5 \mathrm{~N} \mathrm{NaOH}$. One drop of phenol red and $5 \mathrm{ml}$ methanol were added to each tube and the samples were saponified by boiling for $45-60$ min in capped tubes. Following cooling and acidification with $200 \mu 112 \mathrm{~N} \mathrm{HCl}$, fatty acids were extracted three times with $5 \mathrm{ml}$ of petroleum-ether (b.p. $40-60^{\circ} \mathrm{C}$ ). The combined petroleum-ether extracts were evaporated to dryness. Residua were dissolved in scintillation fluid and counted for radioactivity.

The activity of acetyl-CoA carboxylase is expressed as $\mathrm{nmol}$ of malonyl-CoA formed per $\mathrm{min}$. This equals the incorporation of labelled acetyl-CoA into fatty acids in $\mathrm{nmol} / \mathrm{min}$ in the coupled assay.

When the activity of purified acetyl-CoA carboxylase was determined by the bicarbonatefixation assay, the conditions of the acetyl-CoA fixation assay were employed, except that fatty acid synthase, unlabelled $\mathrm{NaHCO}_{3}$ and $\left[1-{ }^{14} \mathrm{C}\right]-$ acetyl-CoA in the assay mixture were replaced by unlabelled acetyl-CoA $(0.062 \mathrm{mM})$ and $\mathrm{NaH}^{14} \mathrm{CO}_{3}$ ( $20 \mathrm{mM} ; 57 \mathrm{Ci} / \mathrm{mol}$ ). The reactions were stopped by the addition of $100 \mu \mathrm{l} 6 \mathrm{~N} \mathrm{HCl}$. Samples were evaporated to dryness and counted for radioactivity.

All results shown are representative experiments confirmed by at least three separate determinations.

Analysis of assay-reaction products by high-performance liquid chromatography. The reaction products formed during the assay were analysed by high-performance liquid chromatography. Analyses were carried out using an LKB liquid chromatograph equipped with a fixed-wavelength ultraviolet detector, a differential refractometer and an Iomess radioactivity monitor (Ramona-LS) with a solid scintillator flow cell. Enzyme reactions were terminated with $\mathrm{NaOH}$. The petroleum-ether extracts (see above) were evaporated to dryness and residua were dissolved in methanol $(90 \%, \mathrm{v} / \mathrm{v})$. Aliquots $(200 \mu \mathrm{l})$ were analysed for $\left[1{ }^{14}\right.$ C]acetyl-CoA fixation into medium- and long-chain fatty acids on an LKB-LiChrosorb C18 
$(10 \mu \mathrm{m})$ reversed-phase column $(4 \times 250 \mathrm{~mm})$. The mobile phase was methanol $(90 \%, v / v)$ with a gradually increasing flow rate from $0.75 \mathrm{ml} / \mathrm{min}$ to $2.0 \mathrm{ml} / \mathrm{min}$ over a period of $15 \mathrm{~min}$. As carriers, $400 \mu \mathrm{g}$ capric and palmitic acid were added to $250 \mu \mathrm{l}$ of the samples. For analysis of the incorporation of label into short-chain fatty acids, the saponified reaction mixtures were extracted three times with $5 \mathrm{ml}$ diethyl ether. The combined diethyl ether extracts were evaporated over $0.1 \mathrm{~N}$ $\mathrm{NaOH}$. The neutralized residua were made $50 \%$ $(\mathrm{v} / \mathrm{v})$ in methanol before HPLC analysis. As carriers, $400 \mu \mathrm{g}$ of each of the following fatty acids were added to $200 \mu 1$ of the samples: butyric, caproic, caprylic and palmitic acid. Analyses for CoA-esters were also made on the reversed-phase column with a solvent system of $50 \mathrm{mM}$ phosphate buffer (pH 5.3)/methanol (90:10, v/v); detection wavelength $254 \mathrm{~nm}$. Unlabelled malonyl-CoA and acetyl-CoA were added as carriers to a final concentration of $100 \mu \mathrm{M}$. In this last case enzyme-reaction mixtures were stopped with $16 \mu 1$ $100 \%$ trichloroacetic acid.

Measurement of fatty acid synthase activity. Fatty acid synthase activity in isolated hepatocytes was assayed as described above for measuring the activity of acetyl-CoA carboxylase except that malonyl-CoA was included and ATP, butyryl-CoA and fatty acid synthase were omitted in the digitonin-containing assay mixture and that the assay period was $10 \mathrm{~min}$.

\section{Results and Discussion}

Isolated hepatocytes have been shown to provide a useful model for studies on metabolic regulation (cf. Ref. 22). Permeabilizing these cells with digitonin [23] opens the possibility of investigating cytosolic enzymes in a more or less natural environment and alleviates the necessity of preparing cellular extracts for enzyme assay. This possibility has been adopted in the present study to rapidly measure hepatocellular acetyl-CoA carboxylase activity. Moreover, ambiguities in existing assays were circumvented by using a coupled assay with added fatty acid synthase.

In developing such a coupled assay for acetylCoA carboxylase in permeabilized cells, the following aspects were addressed: the coupled assay was tested in a cell-free system; the data resulting from this assay were compared with those of a standard assay; the permeability of plasma and mitochondrial membranes was investigated; the linearity of the permeabilized-cell assay as a function of time and protein concentration was considered; the (radioactive) reaction products were identified; and, finally, the applicability of the assay in hepatocytes, incubated under different conditions, was tested.

Coupled assay for measurement of acetyl-CoA carboxylase activity; comparison with the $\mathrm{CO}_{2}$-fixation assay

A number of methods, spectrophotometric and isotopic, for assaying acetyl-CoA carboxylase activity have been described (cf. Ref. 24). Both types of assays can be used only when the enzyme is available in a purified state. They are unsuitable with crude tissue extracts because of interference by side reactions and contaminating enzymes. The isotopic procedures can be employed with subcellular preparations when precautions are taken to avoid contamination of the samples with mitochondrial enzymes. In tissue preparations devoid of mitochondrial enzymes it is still somewhat difficult to measure accurately the enzyme activity by ${ }^{14} \mathrm{CO}_{2}$ fixation because accumulation of malonyl$\mathrm{CoA}$ will lead to product inhibition of the carboxylation reaction [4] and because fatty acid synthase endogenous to the preparation will decarboxylate malonyl-CoA formed in the assay $[10,11]$. These difficulties can be circumvented by coupling the carboxylation reaction with the fatty acid synthase reaction. In this coupled system the rate of formation of labelled malonyl-CoA from radioactive acetyl-CoA is measured by determining the incorporation of ${ }^{14} \mathrm{C}$ into long-chain fatty acids in the presence of an excess of fatty acid synthase $[25,26]$.

In most assay methods for acetyl-CoA carboxylase very high, unphysiological concentrations of citrate are added. Since these will influence the aggregation state of the enzyme, and thereby affect its activity [26], they may well obscure changes in enzyme activity brought about by hormones and other effectors [16]. Therefore, a more physiological citrate concentration of $0.5 \mathrm{mM}$ [27] was used in our assay. 
Radioactive acetyl-CoA may be incorporated into fatty acids without prior conversion into malonyl-CoA, if it is used as a primer of fatty acid synthesis. Since liver fatty acid synthase shows a pronounced preference for butyryl-CoA over acetyl-CoA as primer [28-30], unlabelled butyryl$\mathrm{CoA}$ was included in the reaction mixture for the coupled assay.

For comparison of the coupled assay system with a previously published assay, the activity of a purified acetyl-CoA carboxylase preparation was measured both with the $\mathrm{CO}_{2}$-fixation assay and with the acetyl-CoA fixation assay (Fig. 1). The $\mathrm{CO}_{2}$-fixation assay is linear with time for $4 \mathrm{~min}$, after which the carboxylation reaction slows down, probably as a result of accumulation of malonylCoA [4]. The acetyl-CoA fixation assay is linear with time for at least $9 \mathrm{~min}$, but an initial lag phase of about $30 \mathrm{~s}$ is observed. This lag phase might be caused by the necessity to build up a

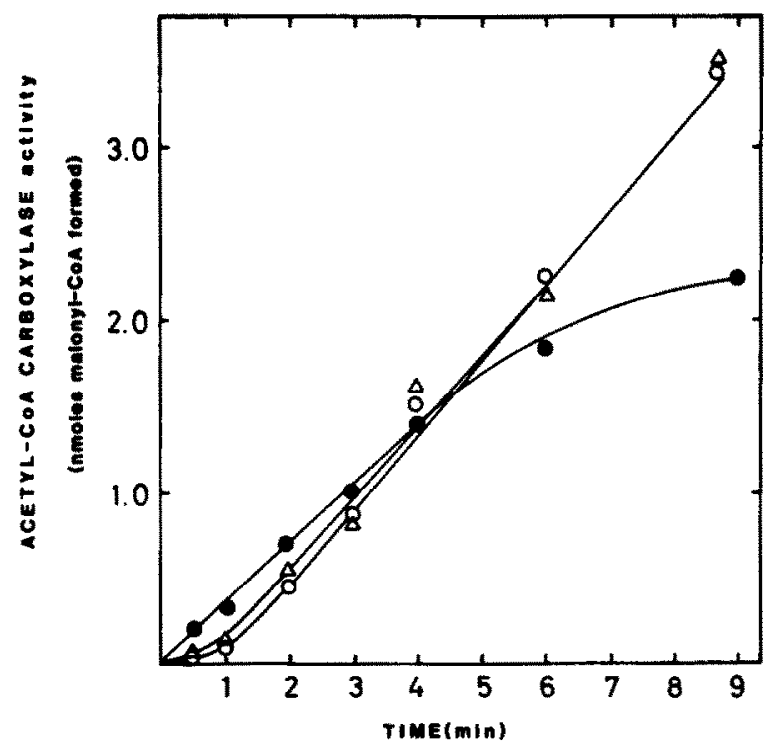

Fig. 1. Activity of purified acetyl-CoA carboxylase as measured by $\mathrm{CO}_{2}(\Theta)$ and acetyl-CoA (O) fixation. Carboxylase preparations were preincubated for $30 \mathrm{~min}$ in the presence of $\mathrm{Mg}^{2+}$, citrate and EGTA, in the same concentrations as used in the assay mixture. In separate acetyl-CoA fixation assays $(\triangle)$, the carboxylation reaction was terminated with $5 \mathrm{mM}$ EDTA at the indicated times and the fatty acid synthase reaction was continued for another $5 \mathrm{~min}$. The data are expressed as nmol formed per assay. The assays contained 0.47 $\mu \mathrm{g}$ carboxylase protein. certain level of malonyl-CoA for the fatty acid synthase reaction [31]. However, such an accumulation of malonyl-CoA could not be demonstrated, since continuation of the fatty acid synthase reaction for another $5 \mathrm{~min}$, after ending the carboxylation reaction by addition of $5 \mathrm{mM}$ EDTA, caused no significant increase of the incorporation of label into fatty acids (Fig. 1). Both assays generate similar activity values around 4 min.

Using crude cell homogenates instead of purified enzyme, the $\mathrm{CO}_{2}$-fixation assay is unreliable even in the first $4 \mathrm{~min}$ of the assay [6-8]. This can be demonstrated by including compounds like $\mathrm{NADH}, \mathrm{NADPH}$ and pyruvate in the assay mixture. These additions have no effect on the acetylCoA fixation assay (not shown).

Permeability of plasma and mitochondrial membranes

Exposure of intracellular acetyl-CoA carboxylase to allow for assay of its activity was achieved by permeabilizing hepatocytes with digitonin. This approach is based on the facts that the cholesterol content of the plasma membrane is higher than that of the mitochondrial membranes [32] and that digitonin reacts specifically with cholesterol [33].

To determine the concentration of digitonin which will allow for measurement of acetyl-CoA carboxylase activity without interference by mitochondrial enzymes, hepatocytes were incubated with increasing concentrations of digitonin. The activity of acetyl-CoA carboxylase was measured with the coupled assay and plotted versus the digitonin concentration (Fig. 2). A concentration of $64 \mu \mathrm{g}$ of digitonin per $\mathrm{mg}$ of cellular protein was most effective in exposing enzyme activity.

With this concentration of digitonin the permeability of plasma and mitochondrial membranes was tested by measuring the release from the cells of lactate dehydrogenase, glutamate dehydrogenase and fatty acid synthase (Table I). Within $15 \mathrm{~s}$ of exposure of cells, digitonin caused the release of more than $95 \%$ of the cytosolic marker enzyme, lactate dehydrogenase. Fatty acid synthase, a much bigger protein molecule than lactate dehydrogenase, is also fully liberated within that period. After $15 \mathrm{~s}$ of exposure to digitonin the 


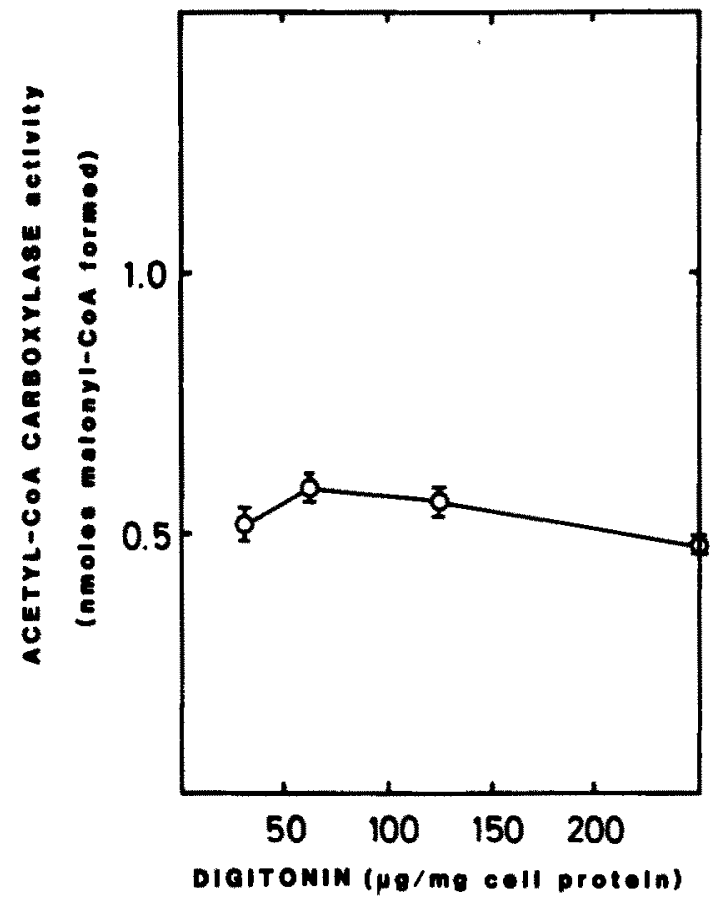

Fig. 2. Acetyl-CoA carboxylase activity in rat hepatocytes permeabilized by digitonin. Freshly isolated hepatocytes were incubated for $15 \mathrm{~min}$ at $37^{\circ} \mathrm{C}$ in Krebs-bicarbonate buffer. Aliquots of the hepatocyte suspension were then transferred to assay mixtures containing varying concentrations of digitonin. The data are expressed as nmol formed per $4 \mathrm{~min}$ assay. The assays contained $0.64 \mathrm{mg}$ protein.

plasma membrane apparently presents no barrier to the diffusion of these enzymes out of the cell. Acetyl-CoA carboxylase, however, was released from the cells much more slowly. After $15 \mathrm{~s}$ of digitonin exposure only $15 \%$ of the carboxylase was released. After $4 \mathrm{~min}$ of digitonin treatment the release of the carboxylase reached a maximum, representing about $30 \%$ of the total activity which can be assayed with our procedure in permeabilized cells. This result shows that in the permeabilized-cell assay the carboxylase activity remaining inside the cells is also measured.

Reports on digitonin release of acetyl-CoA carboxylase from isolated hepatocytes have appeared before [34,35]. In both studies, only the fraction of the enzyme released from the cells was taken into account. Our results indicate that a large difference exists between released and total activity.

\section{TABLE I}

RELEASE OF ENZYMES FROM ISOLATED HEPATOCYTES BY DIGITONIN TREATMENT

Freshly isolated hepatocytes were incubated for $15 \mathrm{~min}$ at $37^{\circ} \mathrm{C}$ in Krebs-bicarbonate buffer. Aliquots of the hepatocyte suspension were then transferred to the digitonin $(64 \mu \mathrm{g} / \mathrm{mg}$ cell protein)-containing assay mixture described for the coupled assay, but without NADPH, ATP, butyryl-CoA, [1${ }^{14} \mathrm{Clacetyl}-\mathrm{CoA}$ and fatty acid synthase. After exposure to digitonin for various periods, the cells were removed by lowspeed centrifugation $(1 \mathrm{~min}, 100 \times g)$. Enzyme activities were determined in the supernatant and expressed as percentages of the total cellular activity. Total cellular activity (100\%) of lactate dehydrogenase was determined after liberation of the enzyme with Triton X-100 $(1.5 \%, v / v)$. Since the Triton treatment results in very low and inconsistent values for acetyl-CoA carboxylase and fatty acid synthase activities, total activities were measured by adding cell suspension to the isotonic digitonin solution. For comparison with the assays carried out in the supernatant, the assays for total activities were also started $15 \mathrm{~min}$ later by completing the assay mixture.

\begin{tabular}{lccl}
\hline $\begin{array}{l}\text { Exposure } \\
\text { time } \\
(\mathrm{min})\end{array}$ & $\begin{array}{l}\text { Lactate } \\
\text { dehydrogenase }\end{array}$ & $\begin{array}{l}\text { Fatty acid } \\
\text { synthase }\end{array}$ & $\begin{array}{l}\text { Acetyl-CoA } \\
\text { carboxylase }\end{array}$ \\
\hline 0.25 & 96.6 & 103.5 & 13.6 \\
1 & 98.6 & 99.7 & 11.2 \\
2 & 95.4 & 100.1 & 14.9 \\
4 & 100.3 & 99.9 & 28.8 \\
10 & 99.2 & 100 & 28.6 \\
\hline
\end{tabular}

Under the conditions employed, the mitochondrial inner membrane shows a complete resistance to damage by digitonin, as indicated by the total latency of the mitochondrial marker enzyme glutamate dehydrogenase. Even after $10 \mathrm{~min}$ of digitonin exposure, less than $1 \%$ of total glutamate dehydrogenase had been released from the cells. In earlier studies [34], it was demonstrated by scanning electron microscopy that treatment of hepatocytes with a digitonin concentration much higher than used in the present study heavily damaged the plasma membrane, but left organelles like mitochondria within the cells, although mitochondrial enzymes were released.

Course of the acetyl-CoA carboxylase assay with time and its relation with protein concentration

After a brief lag phase of about $30 \mathrm{~s}$, we found the acetyl-CoA carboxylase assay in digitonintreated cells to be almost linear with time for 
about $5 \mathrm{~min}$ (Fig. 3A). This lag phase is not caused by a time-dependent change in permeability of the plasma membrane but is a characteristic of the coupled assay because it is also observed with purified carboxylase (cf. Fig. 1). Since no other deviation from linearity occurs in the first few minutes of assay, the exposure of acetyl-CoA carboxylase to assay mixture during permeabilization of intact cells with $64 \mu \mathrm{g}$ digitonin per mg cellular protein must be very rapid. Care was taken to disperse the cells completely in the digitonin-containing reaction mixture at the start of the assay by rapid addition of $0.1 \mathrm{ml}$ of cell suspension to $0.1 \mathrm{ml}$ of pre-heated $\left(37^{\circ} \mathrm{C}\right)$ assay mixture followed by $5 \mathrm{~s}$ gentle vortexing. This procedure ensures an immediate and thorough mixing. Rigorous or prolonged vortexing will result in an impaired assay and eventually in serious damage to the mitochondrial membranes as witnessed by appearance of glutamate dehydrogenase in the extracellular medium (not shown). Settling of permeabilized cells during the assay had no measurable effect upon the linearity of the assay. An assay period of $4 \mathrm{~min}$ was selected for the standard procedure.

The dependence of measured enzyme activity in the permeabilized-cell assay on cellular protein is shown in Fig. 3B. The reaction is linear with

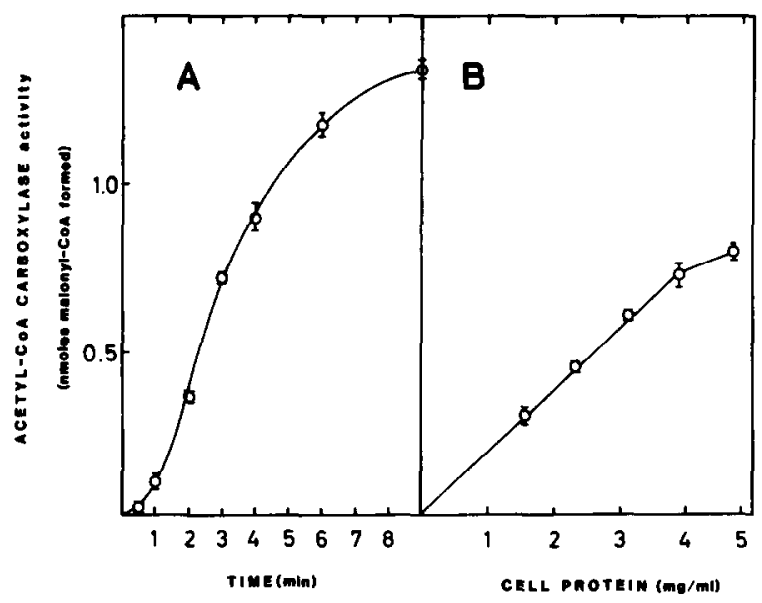

Fig. 3. Acetyl-CoA carboxylase activity in permeabilized hepatocytes as a function of time (A) and protein concentration (B). The data are expressed as nmol formed per assay. In panel $A$ the assay contained $0.64 \mathrm{mg}$ protein; assay time in panel $B$ was 4 min. protein concentrations at least between 1.5 and 4 $\mathrm{mg}$ of cellular protein $/ \mathrm{ml}$ assay volume. Based on these results, the assay was routinely performed with about $3 \mathrm{mg}$ of cellular protein $/ \mathrm{ml}$ assay volume.

\section{Nature of reaction products}

The finding that the $\mathrm{CO}_{2}$-fixation assay for measuring the activity of acetyl-CoA carboxylase in crude homogenates results in bicarbonate fixation into non-volatile and acid-stable compounds other than malonyl-CoA [6-8] prompted us to investigate whether the petroleum-ether-extracted radioactivity from the acetyl-CoA fixation assay in permeabilized cells represents the total of the radioactive reaction products and to analyse these products by HPLC (see Materials and Methods section).

No radioactive malonyl-CoA, malonate and short-chain fatty acids $4: 0,6: 0$ and $8: 0$ could be detected (not shown). Furthermore, no detectable radioactivity was present in the non-saponifiable lipid fraction (not shown). Table II shows that the radioactivity of labelled malonyl-CoA, formed by the carboxylation of $\left[1-{ }^{14} \mathrm{C}\right]$ acetyl-CoA, is converted into petroleum-ether-extractable radioactivity which is mainly present in the fatty acids $14: 0$ and $16: 0$ with minor activity present in $10: 0$, $12: 0$ and $18: 0$. This result is in good agreement with data obtained by Hansen et al. [36], who investigated the identity of the fatty acids formed from $\left[1-{ }^{14} \mathrm{C}\right]$ acetyl-CoA by purified rat liver fatty acid synthase in the presence of varying amounts of purified rat liver acetyl-CoA carboxylase. The 18:0 present in the petroleum-ether extract (Table II) may be partly formed by chain elongation. In that case it must be formed by the malonyl-CoAdependent chain-elongation system in the endoplasmic reticulum rather than by the acetyl-CoAdependent mitochondrial process, since the mitochondria were shown to remain intact during the digitonin exposure (cf. Table I), and acetylCoA will not penetrate into intact mitochondria. Losses via $\beta$-oxidation of fatty acids fromed in the assay were minimal (less than 5\%) (not shown). The presence of unlabelled butyryl-CoA in the assay mixture prevents the utilization of [1${ }^{14} \mathrm{C}$ ]acetyl-CoA as a primer for fatty acid synthesis. This original observation by Singh et al. [30] 
TABLE II

NATURE OF PETROLEUM-ETHER-EXTRACTABLE PRODUCTS SYNTHESIZED BY THE COUPLED ASSAY IN PERMEABILIZED CELLS

Freshly isolated hepatocytes were incubated for $15 \mathrm{~min}$ at $37^{\circ} \mathrm{C}$ in Krebs-bicarbonate buffer. Aliquots of the cell suspension were then transferred to the digitonin $(64 \mu \mathrm{g} / \mathrm{ml}$ cell protein)-containing assay mixture. Reactions were stopped after 4 min by addition of $\mathrm{NaOH}$. The reaction media were saponified and extracted with petroleum-ether as described in the Materials and Methods section. The petroleum-ether extracts were evaporated to dryness, the residua dissolved in methanol and aliquots analysed by HPLC. Of the radioactivity applied onto the HPLC, $91 \pm 2 \%$ was recovered in the indicated fatty acids. The results are the means \pm S.D. for four determinations.

\begin{tabular}{|c|c|c|c|c|c|}
\hline & \multicolumn{5}{|c|}{ Radioactivity incorporated into: } \\
\hline & $10: 0$ & $12: 0$ & $14: 0$ & $16: 0$ & $18: 0$ \\
\hline $\mathrm{dpm}$ & $451 \pm 53$ & $984 \pm 190$ & $3917 \pm 275$ & $4267 \pm 230$ & $616 \pm 133$ \\
\hline $\begin{array}{l}\text { Percent- } \\
\text { age }\end{array}$ & 4.4 & 9.6 & 38.3 & 41.7 & 6.0 \\
\hline
\end{tabular}

was verified under our experimental conditions by showing that in experiments with purified fatty acid synthase, incubated with 5 nmol malonylCoA, the incorporation of $\left[1-{ }^{14} \mathrm{C}\right]$ acetyl-CoA into fatty acids in the presence of butyryl-CoA is less than $4 \%$ of that in its absence. Therefore, the amount of labelled acetyl-CoA incorporated into fatty acids truly represents the activity of acetylCoA carboxylase.

\section{Application of the assay}

To test the applicability of the newly developed enzyme assay in studies on metabolic regulation in rat hepatocytes, changes in the measured activity of acetyl-CoA carboxylase were compared with changes in the rate of fatty acid synthesis, brought about by short-term modulators.

Table III shows that the modulator-determined changes in the rate of fatty acid synthesis were paralleled by changes in carboxylase activity but not by changes in the activity of fatty acid synthase. The correlation was evident only when the carboxylase activity was measured in the presence of a physiological citrate concentration. If $4 \mathrm{mM}$ citrate was added to the assay medium, the effects of the modulators on acetyl-CoA carboxylase activity were hardly detectable (not shown). Pre-incubation of permeabilized cells for $30 \mathrm{~min}$ in the presence of $4 \mathrm{mM}$ citrate resulted in a much higher carboxylase activity, but the modulator-determined differences in enzyme activity disappeared. The latter assay probably reflects the total

\section{TABLE III}

\section{SHORT-TERM EFFECTS OF HORMONES AND PHORBOL ESTER (PMA) ON THE RATE OF FATTY ACID SYNTHESIS AND ON THE ACTIVITIES OF ACETYL-COA CARBOXYLASE AND FATTY ACID SYNTHASE}

Hepatocytes were incubated in the presence or absence of $85 \mathrm{nM}$ insulin, $10 \mathrm{nM}$ glucagon and $1 \mu \mathrm{M}$ phorbol ester with or without ${ }^{3} \mathrm{H}_{2}$ O. From the isotope-free vessels aliquots were removed after $15 \mathrm{~min}$ of incubation for measuring the activities of fatty acid synthase and acetyl-CoA carboxylase in permeabilized cells. In the isotope-containing vessels the rate of fatty acid synthesis was determined from the incorporation of tritium from tritiated water into fatty acids. Results are the means \pm S.D. for three determinations. The numbers in brackets represent percentage of control.

\begin{tabular}{|c|c|c|c|c|}
\hline \multirow[t]{2}{*}{ Additions } & \multicolumn{2}{|c|}{$\begin{array}{l}\text { Acetyl-CoA carboxylase } \\
\text { (nmol acetyl-CoA fixed/mg per min) }\end{array}$} & \multirow[t]{2}{*}{$\begin{array}{l}\text { Fatty acid synthase }{ }^{a} \\
\text { (nmol acetyl-CoA fixed/mg per min) }\end{array}$} & \multirow{2}{*}{$\begin{array}{l}\text { Fatty acid synthesis } \\
\text { (nmol acetyl units } \\
\text { incorporated/mg per min) }\end{array}$} \\
\hline & $\overline{0.5 \mathrm{mM} \text { citrate }^{\mathrm{a}}}$ & $4.0 \mathrm{mM}$ citrate $^{\mathrm{b}}$ & & \\
\hline None & $0.48 \pm 0.04$ & $1.64 \pm 0.17$ & $1.89 \pm 0.16$ & $2.0 \pm 0.3$ \\
\hline Insulin & $\begin{array}{l}0.64 \pm 0.03 \\
(133)\end{array}$ & $1.60 \pm 0.07$ & $1.90 \pm 0.19$ & $\begin{array}{l}2.6 \pm 0.2 \\
(128)\end{array}$ \\
\hline Glucagon & $\begin{array}{l}0.15 \pm 0.02 \\
(31)\end{array}$ & $1.70 \pm 0.19$ & $1.88 \pm 0.16$ & $\begin{array}{l}0.66 \pm 0.1 \\
(33)\end{array}$ \\
\hline PMA & $\begin{array}{l}0.65 \pm 0.09 \\
(135)\end{array}$ & $1.74 \pm 0.08$ & $1.80 \pm 0.22$ & $\begin{array}{l}2.9 \pm 0.2 \\
(145)\end{array}$ \\
\hline
\end{tabular}

\footnotetext{
a Enzymes were assayed exactly as described in the Materials and Methods section.

${ }^{b}$ Cells were pre-incubated with $8 \mu \mathrm{g}$ digitonin/mg cellular protein in the presence of $4 \mathrm{mM}$ citrate. After 30 min pre-incubation, carboxylase activity was determined with the coupled assay; assay time $4 \mathrm{~min}$.
} 
capacity of the carboxylase whereas the activity measured in the presence of a physiological citrate concentration may be representative of the fraction active at the time of permeabilization.

It may be argued that the short-term modulators may change the digitonin-determined permeability of the plasma membrane and thereby affect the extent of assayable carboxylase. The observation that the modulators do not affect the activity of fatty acid synthase - a cytosolic enzyme comparable in size to the carboxylase - is not in line with that argument.

In order to measure enzyme activity we have permeabilized the plasma membrane and this has caused a certain loss of structural integrity of the cell, which may have destroyed the physiological environment of the enzyme. Therefore, it is difficult to make quantitative comparisons between flux rates in the intact cell and enzyme activities in permeabilized cells.

In conclusion, an assay for acetyl-CoA carboxylase, coupled to the fatty acid synthase reaction, has been adopted to allow for the measurement of activity in hepatocytes made permeable with digitonin. Using this assay a good correlation is observed between carboxylase activity and the rate of fatty acid synthesis as influenced by short-term modulators.

\section{Acknowledgements}

The authors wish to recognize the expert technical assistance of Martin Houweling and Karin de Haas. They also express their appreciation to Drs. Anton C. Beynen and Wim. J. Vaartjes for many helpful discussions and Prof. dr. S.G. van den Bergh for reading the manuscript. These investigations were supported by the Netherlands Foundation for Chemical Research (SON) and by the Netherlands Foundation for Fundamental Medical Research (FUNGO) with financial aid from the Netherlands Organization for the Advancement of Pure Research (ZWO).

\section{References}

1 Gibson, D.M., Lyons, R.T., Scott, D.F. and Muto, Y. (1972) Adv. Enzyme Reg. 10, 187-204

2 Allred, J.B., Roman-Lopes, C.R., Pope, T.S. and Goodson, J. (1985) Biochem. Biophys. Res. Commun. 129, 453-460
3 Moss, J. and Lane, M.D. (1972) J. Biol. Chem. 247, 4944-4951

4 Gregolin, C., Ryder, E., Warner, R.C., Kleinschmidt, A.K. and Lane, M.D. (1966) Proc. Natl. Acad. Sci. USA 56, 1751-1758

5 Carlson, C.A. and Kim, K.-H. (1973) J. Biol. Chem. 248, 378-380

6 Buechler, K.F., Beynen, A.C. and Geelen, M.J.H. (1984) Biochem. J. 221, 869-874

7 Davies, D.R., Van Schaftingen, E. and Hers, H.-G. (1982) Biochem. J. 202, 559-560

8 Allred, J.B. and Goodson, J. (1982) Biochem. J. 208, 247-248

9 Scholte, H.R. (1973) Biochim. Biophys. Acta 309, 457-465

10 Yang, P.C., Butterworth, P.H.W., Bock, R.M. and Porter, J.W. (1967) J. Biol. Chem. 242, 3501-3507

11 Yalpani, M., Willecke, E. and Lynen, F. (1969) Eur. J. Biochem. 8, 495-502

12 Holland, R., Witters, L.A. and Hardie, D.G. (1984) Eur. J. Biochem. 140, 325-333

13 Nakanishi, S. and Numa, S. (1970) Eur. J. Biochem. 16, 161-173

14 Linn, T.C. (1981) Arch. Biochem. Biophys. 209, 613-619

15 Seglen, P.O. (1976) Methods Cell Biol. 13, 29-83

16 Geelen, M.J.H., Beynen, A.C., Christiansen, R.Z., Lepreau-Jose, M.J. and Gibson, D.M. (1978) FEBS Lett. 95, 326-330

17 Harris, R.A. (1975) Arch. Biochem. Biophys. 169, 168-180

18 Sundler, R., Akesson, B. and Nilsson, A. (1974) J. Biol. Chem. 249, 5102-5107

19 Bergmeyer, H.U. and Bernt, E. (1970) in Methoden der enzymatischen Analyse (Bergmeyer, H.U, ed.), pp. 533-538, Verlag Chemie, Weinheim

20 Schmidt, E. (1970) in Methoden der enzymatischen Analyse (Bergmeyer, H.U., ed.), pp. 607-613, Verlag Chemie, Weinheim

21 Lowry, O.H., Rosebrough, N.J., Farr, A.L. and Randall, R.J. (1951) J. Biol. Chem. 193, 265-275

22 Harris, R.A. and Cornell, N.W. (1983) Isolation, Characterization and Use of Hepatocytes. Elsevier Science Publishing Co., New York

23 Zuurendonk, P.F. and Tager, J.M. (1974) Biochim. Biophys. Acta 333, 393-399

24 Lowenstein, J.M. (1981) Methods Enzymol. 71, 5-16

25 Wakil, S.J., Porter, J.W. and Gibson, D.M. (1959) Biochim. Biophys. Acta 24, 453-461

26 Matsuhashi, M., Matsuhashi, S. and Lynen, F. (1964) Biochem. Z. 340, 263-289

27 Siess, E.A., Brocks, D.G. and Wieland, O.H. (1976) FEBS Lett. 69, 265-271

28 Lin, C.Y. and Kumar, S. (1972) J. Biol. Chem. 247, 604-610

29 Abdinejab, A., Fisher, A.M. and Kumar, S. (1981) Arch. Biochem. Biophys. 208, 135-145

30 Singh, B., Stakkestad, J.A., Bremer, J. and Borrebaek, B. (1984) Anal. Biochem. 138, 107-111

31 Stern, A., Sedgwick, B. and Smith, S. (1982) J. Biol. Chem. 257, 799-803

32 Colbeau, A., Nachbaur, J. and Vignais, P.M. (1971) Biochim. Biophys. Acta 249, 462-492 
33 Sperry, W.M. and Webb, M. (1950) J. Biol. Chem. 187, 97-105

34 Cook, G.A., Gattone, V.H., Evan, A.P. and Harris, R.A. (1983) Biochim. Biophys. Acta 763, 356-367
35 Meredith, M.J. and Lane, M.D. (1978) J. Biol. Chem. 253, 3381-3383

36 Hansen, H.J.M., Carey, E.M. and Dils, R. (1970) Biochim. Biophys. Acta 210, 400-410 